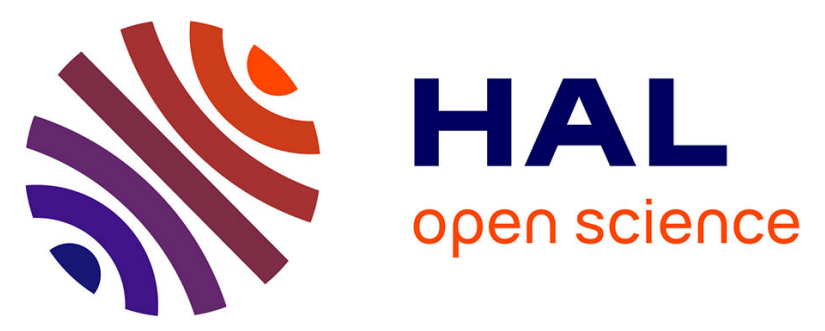

\title{
Insights into the issues facing pharmaceutical companies for information provision: a report on the P-D-R special meeting, La Grande Motte, 28-29 February 2008
}

Lou Ann Di Nallo, Joachim Schöpfel

\section{- To cite this version:}

Lou Ann Di Nallo, Joachim Schöpfel. Insights into the issues facing pharmaceutical companies for information provision: a report on the P-D-R special meeting, La Grande Motte, 28-29 February 2008. Interlending and Document Supply, 2008, 36 (3), pp.158-161. 10.1108/02641610810897881. sic_00376697

\section{HAL Id: sic 00376697 \\ https://archivesic.ccsd.cnrs.fr/sic_00376697}

Submitted on 19 Apr 2009

HAL is a multi-disciplinary open access archive for the deposit and dissemination of scientific research documents, whether they are published or not. The documents may come from teaching and research institutions in France or abroad, or from public or private research centers.
L'archive ouverte pluridisciplinaire HAL, est destinée au dépôt et à la diffusion de documents scientifiques de niveau recherche, publiés ou non, émanant des établissements d'enseignement et de recherche français ou étrangers, des laboratoires publics ou privés. 


\title{
Insights into the issues facing pharmaceutical companies for information provision: a report on the P-D-R special meeting, La Grande Motte, 28-29 February 2008
}

\author{
Lou Ann Di Nallo, Bristol-Myers Squibb
}

Joachim Schöpfel (corresponding author), INIST-CNRS

\begin{abstract}
Purpose: The article reports on the Pharma Documentation Ring (P-D-R) special meeting 2008 on access and use of publishers' content through multiple channels.

Approach: After an introduction to the goals and activities of the P-D-R, we describe the different sessions of the meeting and then summarise the topics related to document supply.

Findings: The article reports on the use of primary information in pharmaceutical companies, on global services arising from national functions, on outsourcing information management, and on technical solutions to control, monitor and limit access. One of the hot topics of the conference was restriction by digital rights management (DRM) measures.

Originality: This report provides insights into the issues currently facing the pharmaceutical industry. The pharmaceutical industry is the only corporate sector with a long and profitable tradition of networking between information professionals.
\end{abstract}

\section{Keywords}

Document Supply, Pharma companies, Pharmaceutical information management, DRM, Information management, Outsourcing, Copyright, Pharma Documentation Ring.

\section{Paper type}

Conference report.

\section{Introduction}

Pharmaceutical companies spend billions of dollars each year on research and development and are heavy consumers of scientific information. Information professionals in the industry began meeting 50 years ago in order to promote the exchange of experience among members, assess new and existing products and services, encourage commercial development of new information services and systems, and provide a forum for the information industry ${ }^{1}$. Presently, this unique association called Pharma Documentation Ring (P-D-R) counts 23 corporate members, including most of the leading "big pharma" companies from Europe and North America.

Nearly 40 publications on information-related issues have been initiated or funded by the PD-R so far ${ }^{2}$, testifying to the great interest in the new technologies of information and

\footnotetext{
Cf. http://www.p-d-r.com

${ }^{2} \mathrm{Cf}$. http://www.p-d-r.com/publications/publications.html
} 
communication. Special interest is paid to copyright and other intellectual property related issues. In 2000, the P-D-R became known to a larger public of LIS professionals because of the Pharmaceutical Model License developed with major STM publishers (Nielsen \& Whittall, 2000) and updated this year (Ditchfield \& Nielsen, 2008).

At the $49^{\text {th }}$ annual meeting in 2007, the P-D-R decided that its "Library Affairs and Copyright Topic Group" should organise a special meeting in early 2008 which would deal with "the complex issues involved in accessing third party full text materials within a global company, including difficulties than can arise from different local copyright situations".

This meeting took place at La Grande Motte near Montpellier (France) on 28-29 February 2008. The overall theme was titled: "Beyond the Model License: Pharma Libraries on the Move - Easy Access \& Use of Publishers' Content Through Multiple Channels: E-License, DocDel, PPV, Print".

75 professionals from 21 pharmaceutical companies, 12 major STM publishers and 12 vendors and Reproduction Rights Organisations (RRO) followed the invitation by SanofiAventis and discussed during two days all facets related to access to scientific information by the corporate sector.

The very rich and dense program included four sessions with eight keynotes, 12 shorter presentations from publishers, document suppliers and RROs, and five round tables and panel discussions.

The meeting participants were welcomed by Oliver Renn (Boehringer Ingelheim), Coordinator of the "Library \& Copyright Affairs Group", who showed a picture of rice field where water is the essential resource. He commented that, for pharmaceutical companies, information is the essential resource. It was intended that this meeting would provide a common understanding and some ideas on how to proceed to make information flow as easily as the water through the rice field.

\section{Session 1: Uses of primary literature in pharma companies}

The first session (chaired by Oliver Renn, Boehringer Ingelheim) on uses of primary literature in pharma companies was opened by Hans-Ulrich Hausermann (Abbott). Primary literature is used by virtually all knowledge workers in a pharma company in two main ways:

- internal for personal use and sharing such as research, training, teaching and collaboration.

- external for medical, health authorities or for marketing purposes.

Examples include - internal or external use of findings from an article; article purchasing on behalf of key opinion leaders, posting articles on public websites, and the ordering of a small number of copies of an article; this last example represents a new line of business for the library as it is a non-typical reprint situation and one which is not easy to achieve for users or publishers.

Henning Nielsen, (Novo Nordisk) was the second speaker, providing insight into the PDR Model License background and recent developments. He started by presenting a short history

\footnotetext{
${ }^{3} \mathrm{Cf}$. http://www.p-d-r.com/pressa/pressa.htm1
} 
of P-D-R/Publishing industry stakeholder relations in the last ten years. The partnership started at a Special Meeting held in May 1998. One outcome was the first working group (1998-2000) which produced a Draft Model License. The P-D-R Task Force on Copyright, which consisted of representatives from P-D-R companies and publishers, was established in 2006. The purpose of the task force was to establish guidelines around copyright issues which would enable pharma companies to better and more easily comply with copyright on purchased, licensed or other legally acquired copyrighted materials. In 2007, the group issued a new Model License. Henning touched on the new parts and revisited parts of the model license as well as what is still missing. In his view, the way to address the issue of what is still missing in the license is to sit down and talk - industry and publishers, and to begin to move away from the "1000 publishers $=1000$ models" to more standardization and possibly to establish consensus guidelines.

So how do pharma companies deal with publishers outside the Model License at present? This question was addressed by Mathias Staab (Sanofi Aventis) who provided insight on current access routes to published content in pharma companies. He presented the results of a survey of P-D-R companies on their use of the model license, pay-per-view and document supply services. The survey revealed that the use of the model license is not a given at companies. The majority of P-D-R companies have licenses with more narrow conditions than allowed in the model license. One of the reasons for this is that the "long tail" of publishers don't offer model license terms, i.e., their terms are more restrictive. Most companies have supplementary license agreements with RRO's (e.g., CCC, CLA, etc.) for print and electronic content. Nearly all companies use some form of pay-per-view (PPV) which offers increased flexibility but at the cost of increased administrative efforts.

Linking tools are well-established as one of the key technologies to pull together different types of resources to maximize value. All companies work with external document suppliers with the majority of companies using their internal print collections for document supply. The final topic of the survey dealt with reprints. Most companies do not coordinate the reprints/eprints activities and most have no insight into the total reprint business in their companies. Those companies that are involved in reprint provision are positioning the need for coordination as a compliance issue.

The morning concluded with statements from three publisher representatives: Peter Katz (Elsevier), Robert Kimberley (Wolters Kluwer) and Janet O'Flaherty (BMJ Group British Medical Association). Generally they are supportive of the idea of the model license. The area of bigger concern is the commercial (marketing) use of their materials and reprints. A lively discussion ensued about reprint rights. It was suggested that two major stakeholders were missing from the discussion - the people at publishers who are responsible for this activity and the marketing people at pharma companies who are the main users. Bringing those parties to the table was raised as a potential topic for a future meeting.

\section{Session 2: Global company services out of national functions}

The afternoon session (chaired by Peter Flodin, Nycomed) looked at the issues from the perspective of document delivery providers and Reproduction Rights Organizations (RRO's). It began with an informative presentation by Casper Grote, Esq. (BASF). Grote's presentation had three aspects: the basic framework of copyright law, the needs and problems of information centres and a "way out of the copyright jungle". The requirements for an ideal 
document delivery system are: international scope, speed, and simplicity with free internal circulation. Unfortunately no current license exists to provide this. Ideally, RRO's should be able to provide these broader rights to companies, similar to the music model although the difficulty of achieving this was recognised..

The program focus shifted next to document suppliers. Are they full-service-providers or just an additional player in the complex game? Representatives from five suppliers were invited to present their views on how they could help integrate services in the future: Petra Labriga (Infotrieve), Peter Derycz (Reprints Desk), Wendelin Detemple (FIZAutoDoc), Mat Pfleger (British Library) and Joachim Schöpfel (INIST) provided their views on how document suppliers can help provide more than just access to non-subscribed content.

Much of the discussion that followed these presentations focused on DRM, which began to emerge as one of the main themes of the meeting, and why pharma companies are hampered by DRM on the content they purchase from document suppliers who are simply doing what the rights owners (publishers) tell them to do. The rights owners are just concerned that their content is only used by the party that purchases it, in the way that it is intended. Pharma companies just want to deliver content to their users in a way that does not frustrate them and interrupt their workflow.

Bob Weiner then gave an overview of the Copyright Clearance Center (CCC). CCC is the largest of the RROs and its mission is to make it easy for users to do the right thing. Weiner described the various services offered by the CCC including; copyright.com, Rightslink, RightsConnect, and Rightsphere. He also spoke about new services including DiscoverWorks.org which addresses orphan works; the experimentation space Copyrightlabs.com; and Mia Della (Fried Rights) which offers commercial use licensing for user-generated content (e.g., blogs, photos, videos), the ALA creative commons license and video and imaging licensing.

Statements were also made by Des Brennan; of the UK CLA and François Gabai, of the French Copyright Center (CFC). Brennan offered an overview of the ABPI Model license for pharma companies. CLA are currently negotiating for the next version of the license which should cover the reuse of digital content, standard terms and conditions, a comprehensive list of digital content included ("opt-in repertoire"), usage reporting, auditing and outsourcing. Gabai explained the role of CFC in France. Only CFC can deliver reprographic licenses on French territory. CFC will start offering licenses in 2008 to each pharma company based in France. The license will be limited to CFC-mandated publications. It aims to meet the needs of users while guaranteeing the rights of rights holders.

The afternoon concluded with a lively discussion during which two themes emerged. One was around paying multiple times for the same rights and a second around "the long tail". Most cases can be dealt with by one or more licenses; what becomes difficult are those things that fall outside the scope of licenses.

\section{Session 3: Outsourcing information management}

Friday morning started with a session (chaired by Carel Fransen, Organon) on outsourcing information management. Lisa Brehm Park described the circumstances leading up to Pfizer's decision to create the STM Library Consortium with Infotrieve and other un-named corporate 
partners. The arrangement allows them to enhance their service delivery while decreasing their costs. Following Brehm Parker, Mick Archer (AstraZeneca) described the pilot they have undertaken with the British Library in which their vision was to become totally virtual. They also wanted to increase the value of their CLA license and the existing collection. Archer described the issues that still need to be addressed: e.g. the need to hold multiple copies, how to deal with DRM, how to make the remote library scalable and transferable.

\section{Session 4: Technical solutions to control, monitor and limit access including missing standards}

The final session (chaired by Carmen Burkhardt, Novartis) dealt with technical solutions to control, monitor and limit access including missing standards. Peter Shepherd of the project COUNTER addressed the question of how we can keep track of what we do, now and in the future. The problem with standards and technology is that by the time they are set, things change and they are out of date.

Following Shepherd, Steve Swain (GlaxoSmithKline) addressed the DRM issues and how the currently conflicting standards are hurting both the pharma companies and the publishers. The driving force on DRM use by document delivery providers is coming from publishers who are worried about control and usage of their content. The problem is that restrictions imposed by DRM can be stricter than rights that otherwise might apply. The challenges are not just technical (e.g., incompatible systems, plugins, etc.), as information center staff find themselves dealing with the problems. DRM is getting in the way of helping their users achieve their business goals. Most users understand the issues but are frustrated by the restrictions and the technology. The ideal solution would be to abolish DRM when working with document suppliers, but in the meantime, document suppliers should work together to ensure consistency in standards. Rights holders should work together to make sure overly restrictive measures are not being enforced and the pharma industry needs to continue to educate rights holders about their own requirements.

The final presentation attempted to describe an ideal system based on the previous discussions. Dan Doran (Roche) laid out the experience of "Alice the Pharma employee" as she used the "iArticle Store" to purchase an article and the rights to use it. The iArticle Store would be a user friendly system with comprehensive publisher coverage which allows for direct access to articles and their use in most situations e.g., internal document supply and sending to external users, with simple, transparent pricing and payment options that support those available from her company.

\section{Concluding remarks}

In the past, Interlending \& Document Supply has published some studies on pharma companies (see Ward 1996, Delaney 2003, Kasarab 2006, Bador et al. 2007). The P-D-R meeting confirmed these companies' constant need for scientific information, expressed their problems with some specific features of document supply, and underlined their interest to find solutions together with the publishers, reproduction rights organisations and intermediaries that are compliant with copyright laws. Concerning document supply, we can highlight five topics: 
- Document supply remains (and so far we can see will remain) one option to access scientific information, especially for the "long tail" not included in subscription licences and estimated at about 12,000 journals.

- Technical measures of protection (DRM) made obligatory by most of the publishers are generally understood but not accepted, because of technical problems (plugins), mutual incompatibility and a too restricted use of documents compared to other licences (CCC, CLA etc.).

- The diversity and complexity of legal conditions that are generally viewed as partly unnecessary limitations to scientific information access.

- Most document suppliers began to develop vendor partnerships in order to enhance their service offer (networking with other suppliers or with Thomson, Google, Ex Libris/SFX, subscription agencies etc).

- Finally, document suppliers are increasingly considered (and wanted) as partners that offer more than simple document supply, e.g. commercial solutions for the outsourcing of other information services ("full service provider").

The P-D-R emphasized their willingness to cooperate with publishers, RROs and document suppliers in order to find pragmatic and reasonable solutions to simplify the legal and technical restrictions. Representatives of some major publishers indicated that the DRM may be a matter of discussion and that it may even be removed some day to give the same usage rights through subscriptions, PPV and document supply. Maybe also, as P. Derycz predicted, DRM will become "technically easier in $2010 "$.

At the last round table of the meeting Bruce Funkhouser (CCC) suggested taking advantage of the actual dynamic and to bring key players together to discuss these issues. A first follow-up will be a meeting of the P-D-R copyright group with CLA and CCC representatives and some document suppliers at the British Library in May or June 2008.

\section{References}

Bador, P., Boukacem-Zeghmouri, C., Lafouge, T., Prost, H. and Schöpfel, J. (2007), "Analysis of the customers of document supply in pharmacology: a case study from INIST in France (part 3)". Interlending \& Document Supply 2007, Vol. 35, No. 3, pp. 138-144.

Delaney, E.L. (2003), "GlaxoSmithKline Pharmaceuticals research and development: document delivery in a global corporate environment", Interlending \& Document Supply, Vol.31, No.1, pp.15-20.

Ditchfield, P.J. and Nielsen, H.P. (2008), "The updated Pharmaceutical Model Licence for Ejournals: a continuing collaboration between publishers and the pharmaceutical industry". Serials, Vol. 21 No. 1, pp. 25-29.

Kasarab, H.V. (2006), "The impact of e-resources on document supply in a corporate pharmaceutical library: the experience of Novo Nordisk", Interlending \& Document Supply, Vol.34, No.3, pp.105-108.

Nielsen, H.P. and Withall, J. (2000), "Model Licensing. Key Elements and Specific Needs in Electronic Journal Licensing for the Pharmaceutical Industry". Serials, Vol. 13 No. 2, pp. 103-109.

Ward, S.E. (1996), "Document delivery: the perspective of industrial information services", Interlending \& Document Supply, Vol.24, No.2, pp.4-10. 


\section{The authors:}

Lou Ann Di Nallo is Director, Information \& Knowledge Integration at Bristol-Myers Squibb and Secretary of the PDR.

P.O. Box 4000, Princeton, NJ 08543

louann.dinallo@bms.com

Joachim Schöpfel is head of the E-publishing and Document Supply Department at INISTCNRS, a lecturer on scientific information at the University of Nancy 2 and member of the research group "Document numérique \& Usages".

INIST-CNRS, 2 allée du Parc de Brabois, F-54519 Vandoeuvre-lès-Nancy Cedex.

schopfel@inist.fr 